Candidate of Pedagogical Sciences, Associate Professor, Head of Foreign Language and Methodologies Department, Pedagogical Institute, Borys Grinchenko Kyiv University, blvd. I. Shamo, 18/2, 02154 Kyiv, Ukraine, n.kosharna@kubg.edu.ua

\title{
MODERN EUROPEAN EXPERIENCE OF PRACTICAL TEACHER TRAINING
}

The article considers the issue of studying modern European experience of practical teacher training. It was found out that efficiency of preparing future teachers to their practical activity directly depends on all the levels - from top to bottom - state educational policies and support, regulations in the field of teacher training, modern initial teacher training programmes, inner motivation to become a teacher. It is pointed out the need to apply an integrated approach in mastering the readiness to follow the profession. As we are talking about the European experience, a special attention is paid to study and analysis of regulatory European framework. It helps to define new strategies of developing practical teacher training system, offers recommendations on efficiency of implementing innovative methods and technologies in teacher training process. According to some reports of European Commission, the effectiveness of teacher training is determined by comprehending the teaching profession and the professional development of teachers as a coherent continuum with several, interconnected perspectives, which include teachers' learning needs, support structures, job and career structures, competence levels and local school culture. Within practical teacher training there is a special role of partner schools where a special position belongs to a school-based teacher/ educator, who does his/ her duties on the basis of a partner school. That educator teaches pupils at school and has responsibilities to support partnership with a teacher training university or college in providing the practical training of students - future teachers. It means to be a mentor/ facilitator/ cooperating teacher. It is found out that basis of training is the practical formation of qualities which are essential for the future teacher's practical training. Students are educated to develop such pedagogical characteristics as flexibility, reflexivity, awareness of the internal ambiguity of positions and points of view, ability to take alternative decisions and to form the following basic personality traits as sociability, creativity, mobility, independence, responsibility for the personal choice, decision and the results of the teachers`activities.

Keywords: European experience; partner school; pedagogical specialties, practical training; teacher training; technological knowledge 
(C) Kosharna N., 2021

https://doi.org/10.28925/2312-5829.2021.1.10

Introduction. The question of effective practical teacher training is in the focus of leading European countries`attention. Over the last ten years, a number of important studies have been done in the field of teacher training. Such organizations as the Education Information Network in Europe, consisting of a coordinating European Unit and a series of national units (Eurydice Network), and European Commission's Centre for Research on Education and Lifelong Learning (CRELL) have presented special reports with up-to-date information concerning the policy decisions in the Education field. For example, the Eurydice Network's "The Teaching Profession in Europe. Practices, Perceptions and Policies" considers a comprehensive overview of the teaching profession in Europe, provides analyses key components of teacher initial education and early career support, examines needs and provision of continuous professional development, provides an overview of teachers' transnational mobility, and analyses the link between job satisfaction, perception of value of the profession, and working conditions (European Comission: Educating and Training, 2015, p. 1).

It is impossible not to agree that the effectiveness and efficiency of teacher training in accordance with modern world challenges, first of all, depends on the understanding of the teaching profession and the professional development of teachers as a coherent continuum with several, interconnected perspectives, which include teachers' learning needs, support structures, job and career structures, competence levels and local school culture. To have a successful system of teacher training, it should be started with state regulations and policies in the educational field, government's responsibility to take measures to raise the quality of teaching by enhancing initial teacher education programs and teachers`awareness in their more professional development linked to tailoring, diversifying, and innovating teaching practices (European Comission: Educating and Training, 2015, p.2).

Organizing and conducting practical teacher training, the unity of social and pedagogical dimensions of the teacher's activity should be taken into account. 
Analysis of the literature on the research problem. The priorities of modern education are defined in the normative documents of international conventions. They are the roadmaps for reforming Ukrainian science and moving towards integration into European communities (Palamar, Nazarenko, Vaskivska et al., 2020, p.2657).

Considering the task of effective practical teacher training, it is important to learn the basics of European Union educational policy which is paying attention to the knowledge, skills and attitudes of future teachers, working teachers and school leaders, who are responsible for this process too (European Commission, 2013).

Providing future teachers with practical training, they should be taught that teachers' continuing professional development is a crucial element in ensuring the quality of what children experience through their education. As the teachers involved and gained knowledge, skills and experience, their increased confidence and expertise subsequently affects all children within their classrooms (Altun, 2011).

In the process of practical teacher training it is important to take into consideration the future teacher's activity, his / her cooperation with pupils. The important thing is the teacher`s ability to solve the problem, and this feature is not limited to mastering a certain set of skills. This ability has several components: motives of activity; ability to navigate in the sources of information; skills necessary for certain activities; theoretical and applied knowledge required for understanding the essence of the problem and choosing ways to solve it (Palamar, 2018, p. 274).

Using informational and communicational training technologies, including specific methods and technical means (computers, audio and video, telecommunication networks, etc.) for working with information makes the process of practical teacher training more informative and successful (Petryk, 2020). Today, this type of pedagogical technologies is designated by the term «computer technology of instruction», which continues to develop the ideas of programmed instruction, opening up new technological possibilities of educational process with advantages connected with computers and telecommunications (Terletska, 2018, p. 130).

Within profile training implementation, it could be pointed that an analysis of pedagogical practice makes it possible to note that today, the appropriate methods and 
approaches, properly selected by the teachers, are essential in the system of studying. For example, language disciplines, in particular foreign languages during profile training implementation (Yuzkiv, H., Ivanenko, I., Marchenko et al., 2020).

If we are speaking about practical training of primary or preschool foreign language teachers, it should be remembered that the main purpose of language education in primary school is to provide pupils general development, to form their motivation to learn foreign language, to develop their ability to listen and understand a foreign speech, to teach reading and writing on the basis of an available linguistic theory to form practical abilities and skills (communicative), and the most important thing is to form the ability to learn (Kotenko, Kosharna \& Holovatenko, 2020). So, well-mastered theoretical positions without their usage into pedagogical practice do not guarantee the success of the teacher's professional activity.

The purpose of the article is to study the modern European experience of practical teacher training and to find out its peculiarities.

To achieve the purpose following research methods were used observation, description, analysis of the regulatory framework, study and generalization of scientific publications, comparison.

The key definitions concerning practical teacher training. In most European Union research documents on education it is pointed out a term general pedagogical knowledge. In 2015, this term was presented in the European Paper «Educational Research and Innovation Pedagogical Knowledge and the Changing Nature of the Teaching Profession» (2017). The term general pedagogical knowledge (GPK) is interpreted as the specialized knowledge of teachers for creating and facilitating effective teaching and learning environments for all students independent of subject matter. in creating and facilitating effective teaching and learning environments for all students, independent of subject matter (Guerriero (ed.), 2017, p. 80).

Having analyzed the scientific works on the problem, we can point out a high frequency of using one more term - pedagogical content knowledge (PCK). This term is also often declares in European reports on the teacher training. According to Shulman`s definition, PCK means knowledge of content pedagogy, or blending of content and 
pedagogy into an understanding of how particular topics, problems or issues are organized, represented and adapted to the diverse interests and abilities of learners and presented for instruction (Shulman, 1987).

Having investigating practical teacher training, we should understand the original meaning of term technological pedagogical content knowledge (TPACK) that is teacher's knowledge of how to coordinate subject- or topic-specific activities with topic-specific representations (i.e. examples, models, analogies etc.) using emerging technologies with the intent of facilitating student learning (Cox \& Graham, 2009). Technological pedagogical content knowledge has also been conceptualized as having three main elements including knowing where in the curriculum to include technology, which technology specifically to use and lastly, how to teach with it (McCrory, 2008).

If we are dealing with a practical component within teacher training, it is necessary to take into consideration the meaning of term practical training. This term practical training is explained in the documents of Independent Organization for Economic Cooperation and Development (France) as practical teaching experience undertaken as part of an initial teacher education programme, which allows prospective teachers to observe, document, discuss and eventually perform in the role of a teacher, under the guidance of more experienced teachers, mentors and/or teacher educators. In some countries, this is known as a «practicum», which occurs in blocks of time over the course of an initial teacher education programme; «clinical experience», which follows the medical model embedding theory with practice so practical training and university-based learning often occur at the same time; or an «internship», where students take-on a full-time placement, with the expectation of greater teaching responsibilities and may receive a stipend (OECD, 2018).

In the context of teacher training, it is used some terms as initial teacher education (ITE) and initial teacher preparation (ITP), which are met in European educational regulations:

- ITE means education and training received by a teacher candidate as part of his/her initial teacher education programme, which may be undertaken in a teacher education institution, school or on-line; 
- ITP means a composite of pre-service education and support for new teachers as part of in-service education (OECD, 2018).

After preparing students of pedagogical specialty to the future profession, they should be ready to meet with as opportunity (a high status of teacher profession) as threat (loss of motivation to work as a teacher). To deal with such challenges, future teachers need to be equipped with a set of modern key competences - including literacy, numeracy and digital competence. Critical thinking, creativity and the ability to work as part of a team are equally important to build sustainable careers and become active citizens (Council of the European Union, 2018).

Nowadays, both in Ukraine and in some other national systems there is a problem of preparing teachers who do not follow their profession in future. European Trade Union Committee for Education did some researches. They conclude that a current problem, which is growing, is that of the «pool of inactive teachers»- people who have trained as teachers but who for whatever reason, have left the profession. The task should be to provide future teachers, educators with correct practical training on the level of Initial Teacher Education. It could help to prepare them to be active in the profession. They will understand the high status of pedagogical career and professional development (ETUCE, 2008, p. 14).

Initial Teacher Education is a fundamental area in which to support the shift towards new working cultures and to lay the foundations for teachers' capacity to adapt to changing contexts and circumstances. It is ideally positioned to play a key role in achieving two key goals: improving the development of teaching practices; and, attracting more high quality candidates to the teaching profession (European Commission, 2015).

According to the Plan of Improving Initial Teacher Education, developed by European Commission with a purpose to build a European Education Area, it is necessary to understand the teaching profession and the professional development of teachers as a coherent continuum with several, interconnected perspectives, which include teachers' learning needs, support structures, job and career structures, competence levels and local school culture. Teachers should be able to develop and maintain a mindset and a practical approach which are based on reflection and inquiry, and focused on ongoing professional 
development. Initial Teacher Education needs to be considered as a starting point for this ongoing process of professional development. It lays the foundation for this mindset and this approach (European Commission, 2020, p. 15).

Within studying the modern European experience it is important to look at the Analysis of Teaching and Learning International Survey (TALIS) data:

- more than nine out ten teachers in Europe have completed Initial Teacher Education $(91.2 \%)$. A large majority of these teachers $(80 \%)$ say that their studies included the three essential elements of content, pedagogy and practice. Italy (53.3\%), Spain (63.2\%), France (74.8\%) and Serbia (75.5\%) are notable exceptions in this respect. The same analysis shows that at EU level, teachers feel better prepared for the different aspects of their job if they have completed an Initial Teacher Education programme. The overall feeling of preparedness is higher in relation to the 'content' of teaching (subject knowledge) than to its 'pedagogy' (understanding of teaching and learning) and 'practice' (classroombased training) (European Commission: Educating and Training, 2015).

\section{Studying the question of practical teacher training in some countries as Great} Britain and Sweden (Kosharna N., Zhuravlova L., Nieliepova et al., 2020), Germany (Solomakha, 2018), we may conclude that teacher education courses have varied in length, and this is determined by a number of educational and social circumstances, but all of them go directly to a pedagogical / teaching career. The special position in the process of practical teacher training belongs to school-based teacher/ educator, who does his/ her duties on the basis of a partner school. That educator teaches pupils at school and has responsibilities to support partnership with a teacher training university or college in providing the practical training of students - future teachers. It means to be mentor/ facilitator/ cooperating teacher.

Examining the content and features of the organization and implementation of the practical component of future teachers` professional trainin, for example, in Swedish universities, we may state that pedagogical practice develops future teachers`creative activity and forms professional skills, educates professional qualities - love for children, humanism, pedagogical insight, the ability to use means of verbal and nonverbal self- 
expression, discovers interest in teaching profession, forms an individual style of activity. This is facilitated by its content and structure (Kosharna, 2018).

The author of the article, while being on practice and observing the system of teacher training in Sweden - Malmö School of Education and then Malmö University, Lund University, Halmstad University, found out that practical teacher training is a complex process with a main accent upon pedagogical practice. It helps students to master certain skills and abilities through which they as future teachers will be able to plan and conduct lessons, interact with other participants in the educational process. The programme of practical and pedagogical training is based on the main components - the teacher`s skills:

- identification - the student's ability to reflect in practice their own theoretical knowledge; - knowledge - the ability to teach pupils and to make didactically correct decisions;

- communication - the ability to speak within professional discourse, to make contacts with pupils, their parents and colleagues, to explain the didactic material to pupil;

- leadership - to exercise democratic management, to motivate pupils to act toward achieving a common goal.

Each group of skills contains a substructure consisting of four levels: from the future teacher-beginner to the future teacher-professional (master). These levels of pedagogical practice determine the main requirements facing students, namely:

- direct the future teacher to achieve a common goal: skills should not change at different levels, they should expand and deepen (a principle of horizontal distribution);

- ensure uniformity of the general description of levels and equivalence of the general quality of the requirements put forward within the same level;

- determine the positive qualities that are formed in the future teacher during pedagogical practice;

- determine the general requirements for the student's pedagogical practice (they can be adjusted depending on the conditions in which the partner school operates) (Lärarprogrammet, 2005).

Studying the experience of Sweden in the field of practical teacher training, we can underline that the components of practical pedagogical training make it possible to 
combine and coordinate theoretical and practical elements of teaching, synthesize scientific knowledge and practical skills, to form their own style of professional activity. Qualitative training of future teachers depends on a well-established practice based on educational institutions. It is an establishment of partnerships between universities and general education schools / kindergartens to promote high-quality professional training for future teachers. Such cooperation is determined as partner schools/ institutions (Holmberg, 2006).

Therefore, pedagogical practice is entrusted with key tasks in teacher training. The implementation of these tasks should help the public itself, which should be interested in quality training of future teachers.

Conclusions. As we talk about European experience, a special attention is paid to the study and analysis of the normative European legal framework, which helps to identify new strategies for the development of practical teacher training, to form recommendations on the effectiveness of innovative methods and technologies in teacher training. A special role in this issue is played by the partner school as a basic institution for organizing practical teacher training. It should take into consideration the unity of social and pedagogical dimensions of the teacher .

Analyzing modern European experience in the issue of practical training, it is necessary to underline the social and pedagogical dimensions that regulate and manage the teacher`s activities. The social dimension regulates the responsibility of the teacher in relations with society (educating children and taking care about them). The pedagogical dimension regulates the didactic activity of the teacher, within which the goals of education are realized. The organization of practical training of future teachers determines its importance as a special factor in the formation of a specialist for all educational levels. In addition, one more important marker is the need to form the qualities whish should be used in practical training of future teachers. Students are taught to develop such pedagogical characteristics as flexibility, reflexivity, pedagogical professional communication, ability to make alternative decisions, and, in addition, students are helped to form such personality traits as sociability, creativity, mobility, independence, responsibility for their behavior, personal choice to make professional decisions as 
teachers.

\section{References}

Altun, T. (2019). INSET (In-Service Education and Training) and Professional Development of Teachers: A Comparison of British and Turkish Cases. US-China Education Review, A 6, 846-858. URL: https://www.academia.edu/4711609/INSET_In_Service_Education_and_Training_ and_Professional_Development_of_Teachers_A_Comparison_of_British_and_Tur kish_Cases (eng)

Council of the European Union (2018). Council Recommendation on Key Competences for Lifelong Learning. Interinstitutional File: 2018/0008. 29. URL: https://eurlex.europa.eu/legalcontent/EN/TXT/PDF/?uri=CONSIL:ST_9009_2018_INIT\&fro $\mathrm{m}=\mathrm{EN}$ (eng)

Cox, S., Graham, Ch.R. (2009). Diagramming TPACK in Practice: Using an Elaborated Model of the TPACK Framework to Analyze and Depict Teacher Knowledge. TechTrends. 53(5). Article 60. DOI:10.1007/s11528-009-0327-1 (eng)

Educational Research and Innovation Pedagogical Knowledge and the Changing Nature of the Teaching Profession (2017). Edited by Guerriero Sonia. 278. URL: http://www.oecdteacherready.org/resources/ (eng)

ETUCE. Teacher Education in Europe: policy paper (2008). URL: https://www.researchgate.net/publication/325271454_Teacher_Education_Policy_ and_Practice_in_Europe_Challenges_and_Opportunities

European Commission (2013). Study on Policy Measures to improve the Attractiveness of the Teaching Profession in Europe: Final Report. Vol. 2. 400. URL: https://ec.europa.eu/assets/eac/education/library/study/2013/teachingprofession2_en.pdf (eng)

European Commission: Educating and Training (2015). Strengthening teaching in Europe. New evidence from teachers compiled by Eurydice and CRELL, June 2015. URL: https://ec.europa.eu/assets/eac/education/library/policy/teaching-professionpractices_en.pdf (eng)

European Commission (2015). Shaping career-long perspectives on teaching: A guide on policies to improve Initial Teacher EducationEducation \& Training 2020 - Schools Policy. Luxembourg: Publications Office of the European Union. 87. URL:https://www.schooleducationgateway.eu/downloads/files/Shaping\%20careerlong\%20perspectives\%20on\%20teaching.pdf (eng)

European Commission (2020). The importance of professional development for teachers and school leaders. URL: https://ec.europa.eu/assets/eac/education/library/study/2013/teachingprofession2_en.pdf (eng)

Holmberg, O. (2006). Students' Identification Levels: Handbookfor teachers and Students. Malmo. 25. (eng)

Kosharna N., Zhuravlova L., Nieliepova A., Sidorova I., Lopatynska N. Professional training of primary school teachers (experience of Great Britain, Sweden) / 
Applied Linguistics Research Journal (İstanbul (Turkey), 2020. - 4 (9). - P. 159173. DOI: $10.14744 /$ alrj.2020.82712 (eng)

Kotenko, O., Kosharna, N., Holovatenko, T. (2020). Pre-service Primary School Teacher's Foreign Language Training by Means of Using Innovative Technologies. International Perspectives on Creativity in the Foreign language Classrooms /edited by Papadopoulos, I., Griva, E. and Theodotou, E. New York: Nova Press Publishing. Chapter 11, 257-280. ISBN: 978-1-53618-085-5 (eng)

Organisation for Economic Co-operation and Development. Initial Teacher Preparation study: Glossary (2018). URL: http://www.oecdteacherready.org/resources/ (eng)

McCrory, R. (2008). Science, technology, and teaching: The topic-specific challenges of TPCK in science. Handbook of technological pedagogical content nowledge (TPCK) for educators (AACTE Committee on Innovation and Technology (Ed.),) (pp. 193-206). New York: Routledge URL: https://www.punyamishra.com/wpcontent/uploads/2008/05/koehler_mishra_08.pdf (eng)

Palamar, S.P. (2018). Kompetentnisnyy pidkhid yak metodolohichnyy oriyentyr modernizatsiyi suchasnoyi osvity [Competence approach as a methodological landmark of modernization of modern education]. Educological Discourse, 1 - 2 (20-21), 267 - 278. DOI: 10.28925/2312-5829.2018.1-2.77621 (ukr).

Palamar, S.P., Nazarenko, L.A., Vaskivska, H.O., Nezhyva, L.L., Golota, N.N., Zhelanova, V.V. (2020). Formation of educational and cognitive competency of junior specialists in the process of self-educational activity: experiencial aspect. Wiadomości Lekarskie. 2020. LXXIII (12). 2657-2664. ISSN 0043-5147. (eng)

Petryk, L. (2020). Interaktyvne navchal'ne seredovyshche protsesu inshomovnoyi pidhotovky maybutnikh uchyteliv pochatkovoyi shkoly [An interactive educarional environment of the process of future primary school teachers` foreign language training]. Innovative pedagogy. Issue 25, Volumes 2. 138-142. (ukr).

Solomakha, A. (2018). Zmishane navchannya studentiv-mahistrantiv za spetsial'nisttyu «metodyka rann'oho navchannya ditey inozemniy movi»: dosvid Nimechchyny [Blended learning of master students for the specialty «Methods of early learning of foreign languages»: experience of Germany] Pedahohichnyy protses: teoriya $i$ praktyka, 4 (59), 136-140 (ukr).

Strengthening teaching in Europe: New evidence from teachers compiled by Eurydice and CRELL (2015).

URL:

https://ec.europa.eu/assets/eac/education/library/policy/teaching-professionpractices_en.pdf (eng)

Shulman, L. Knowledge and teacher foundations of the New Reform (1987). Harvard $\begin{array}{lllll}\text { Educational } & \text { Review. } & \text { Vol. } & 57 & \text { (1): }\end{array}$ https://doi.org/10.17763/haer.57.1.j463w79r56455411 (eng)

Terletska, L. (2020). Modern technologies of teaching English language of students of pedagogical specialties. Pedahohika formuvannya tvorchoyi osobystosti u vyshchiy $i$ zahal'noosvitniy shkolakh. Vol. 3 (69). 129-132. DOI https://doi.org/10.32840/1992-5786.2020.69-3.26 (eng)

Vägledning till dina studier på lärarprogrammet. - Malmö högskola: lärarutbildningen, 2005. - 10 p. (swedish) 
Yuzkiv, H., Ivanenko, I., Marchenko, N., Kosharna, N., Medvid, N. (2020). Innovative Methods in Language Disciplines During Profile Training Implementation / International Journal of Higher Education 9(7):230 DOI: 10.5430/ijhe.v9n7p230 (eng)

\title{
СОВРЕМЕННЫЙ ЕВРОПЕЙСКИЙ ОПЫТ ПРАКТИЧЕСКОЙ ПОДГОТОВКИ УЧИТЕЛЕЙ
}

\author{
Наталья Кошарная, кандидат педагогических наук, доцент, \\ заведующая кафедры иностранных языков и методик их обучения \\ Педагогического института, \\ Киевский университет имени Бориса Гринченко, \\ бул. И. Шамо, 18/2, 02154 г. Киев, Украина
}

В статье рассматривается вопрос необходимости изучения современного европейского опыта практической подготовки учителей. Изученные материаль показывают, что эффективность подготовки будущих учителей к их практической деятельности напрямую зависит от всех уровней, а именно - образовательной политики и поддержки государства, законодательной основы в сфере педагогической подготовки, современных программ базовой подготовки учителей, внутренней мотивачии стать учителем. Указывается на необходимость применения комплексного подхода к формированию готовности к педагогической профессии. Поскольку мы говорим о европейском опыте, особое внимание уделяется изучению и анализу нормативной законодательной европейской базы, что помогает определить новые стратегии развития системы практической подготовки учителей, выстраивает рекомендации по эффективности внедрения инновационных методов и технологий в процесс подготовки учителей. Особую роль в этом вопросе играет партнерская школа как еще практическая база подготовки учителей. Нужно принять во внимание необходимость формирования качеств, необходимых для практической подготовки будущего учителя

Ключевые слова: европейский опыт; партнерская школа; педагогические специальности; практическая подготовка; знание технологий.

\section{СУЧАСНИЙ ЄВРОПЕЙСЬКИЙ ДОСВІД ПРАКТИЧНОЇ ПІДГОТОВКИ ВЧИТЕЛІВ}

Наталія Кошарна, кандидат педагогічних наук, доцент, завідувачка кафедри іноземних мов і методик їх навчання

Педагогічного інституту,

Київський університет імені Бориса Грінченка, бул. І. Шамо, 18/2, 02154 м. Київ, Україна

Стаття присвячена питанню необхідності вивчення сучасного європейського досвіду практичної підготовки вчителів. Дослідження наукових робіт вітчизняних та зарубіжних дослідників показує, щуо ефективність підготовки майбутніх 
учителів до їх практичної діяльності безпосередньо залежить від всіх рівнів, а саме: освітньої політики $i$ підтримки держави, законодавчої основи у сфері педагогічної підготовки, сучасних програм базової підготовки вчителів, внутрішньої мотивації стати вчителем. Вказано на необхідність застосування комплексного підходу до формування готовності студентів до педагогічної професії. Оскільки ми говоримо про європейський досвід, особливу увагу приділено вивченню та аналізу нормативної законодавчої європейської бази, щзо допомагає визначити нові стратегї розвитку системи практичної підготовки вчителів, вибудовує рекомендації щзодо ефективності впровадження інноваційних методів та технологій в прочес підготовки вчителів. У прочесі практичної підготовки особливу роль відіграє партнерська школа як практична база підготовки вчителів. Засвоєні студентами теоретичні знання мають бути практично і системно застосовані $y$ партнерській школі, щзо забезпечить практичну професійну підготовку майбутнього педагога. Доведено, щуо на педагогічну практику покладають ключові завдання у підготовці педагогів. Аналізуючи досвід окремих країн у питанні практичної підготовки, варто взяти до уваги соцуільний та педагогічний виміри, які регламентують діяльність педагога. Соціальний вимір регламентує відповідальність педагога перед суспільством за виховання кожної конкретно взятої дитини, виконання першочергово завдання вчителя - здійснення турботи про учнів. Педагогічний вимір регламентує дидактичну діяльність педагога, у межах якої відбувається реалізація цілей освіти. Організація практичної підготовки майбутніх педагогів з урахуванням зазначених вище вимірів обумовлює ї̈ значущість як вагомого чинника формування фахівия для всіх ланок освіти. Окрім того, важливим маркером є необхідність формування якостей, необхідних для практичної підготовки майбутнього вчителя. Студентів навчають розвивати такі педагогічні характеристики як гнучкість, рефлексивність, педагогічна професійна комунікація, здатність приймати альтернативні рішення, $i$, крім того, студентам допомагають сформувати такі риси особистості як товариськість, креативність, мобільність, незалежність, відповідальність за свою поведінку. особистий вибір, рішення і результати діяльності вчителів.

Ключові слова: європейський досвід; партнерська школа; педагогічні спеціальності; практична підготовка; знання технологій.

Стаття надійшла до редакизї 05.01.2021 Прийнято до друку 25.02.2021 